\title{
THE RESISTANCE OF SOME POTATO VARIETIES TO SPRAING CAUSED BY TOBACCO RATTLE VIRUS
}

\author{
EsKo SEPPÄNEN \\ Department of Plant Pathology, Agricultural Research Centre
}

Received March 7, 1972

\begin{abstract}
TRV was detected and identified for the first time in Finland. According to the information available rattle is an uncommon potato disease in our country. Spraing symptoms were detected in tubers grown in a trial field at Tikkurila in 1968, and during the following years it was possible to make observations on the resistance of 10 varieties to the disease. Sieglinde and Pito were most susceptible followed by Jaakko, Eigenheimer, Olympia and Valtti. Amyla, Record and Realta were fairly resistant and Bintje most resistant.
\end{abstract}

According to Calvert and Harrison (1966) there are 2 viruses which cause spraing in potato tubers: tobacco rattle virus (TRV) and potato mop top virus (PMTV). The former is transmitted by nematodes of the genus Trichodorus and the latter by a fungus Spongospora subterranea (Wallr.) Lagerh., the causal agent of powdery scab. To the present, PMTV has occurred chielfly in Great Britain where, according to Calvert (1970), it is widespread. The occurrence of TRV either under the name "rattle» or its synonyms is more common. In addition to its occurrence in Great Britain (e.g. Cadman and Harrison 1959, Todp 1965) it has been detected in the Netherlands (RoozendaAl 1947, RoozendaAl and van der Want 1948), in Denmark (Hansen 1962, Kristensen 1962, Kristensen and Engsbro 1966), in Norway (BJørnstad 1962, cf. Bjørnstad 1969), in Sweden (Lihnell 1958, Persson 1968) and in the USA (Walkinshaw and Larson 1959).

This paper is the first report on the occurrence of TRV in Finland and also summarizes observations of varietal resistance to spraing.

\section{Materials and methods}

I dentific a tion of TRV. Tobacco rattle virus was identified by means of test plants Nicotiana tabacum L. (Samsun) and Chenopodium amaranticolor Coste and Reyn, with which TRV can be distinguished from PMTV (CAlvert and Harrison 1966, ToDD 1967). It was transmitted directly to leaves by rubbing with cut surfaces of tubers having spraing symptoms and by means of juice from infected tobacco roots. The symptoms in test plants were similar to these described by Calvert and Harrison (1966), 
Kristensen and Engsbro (1966), Todd (1967), i.e. necrotic spots in tobacco and chlorotic spots (1-2 $\mathrm{mm}$ in diameter) in C. amaranticolor (Fig. 1). Soil samples from the trial field were examined by Mr. O. Roivainen of the Department of Pest Investigation. The nematode Trichodorus pachydermus Seinhorst, a vector of TRV (SOL et al 1960), was detected.
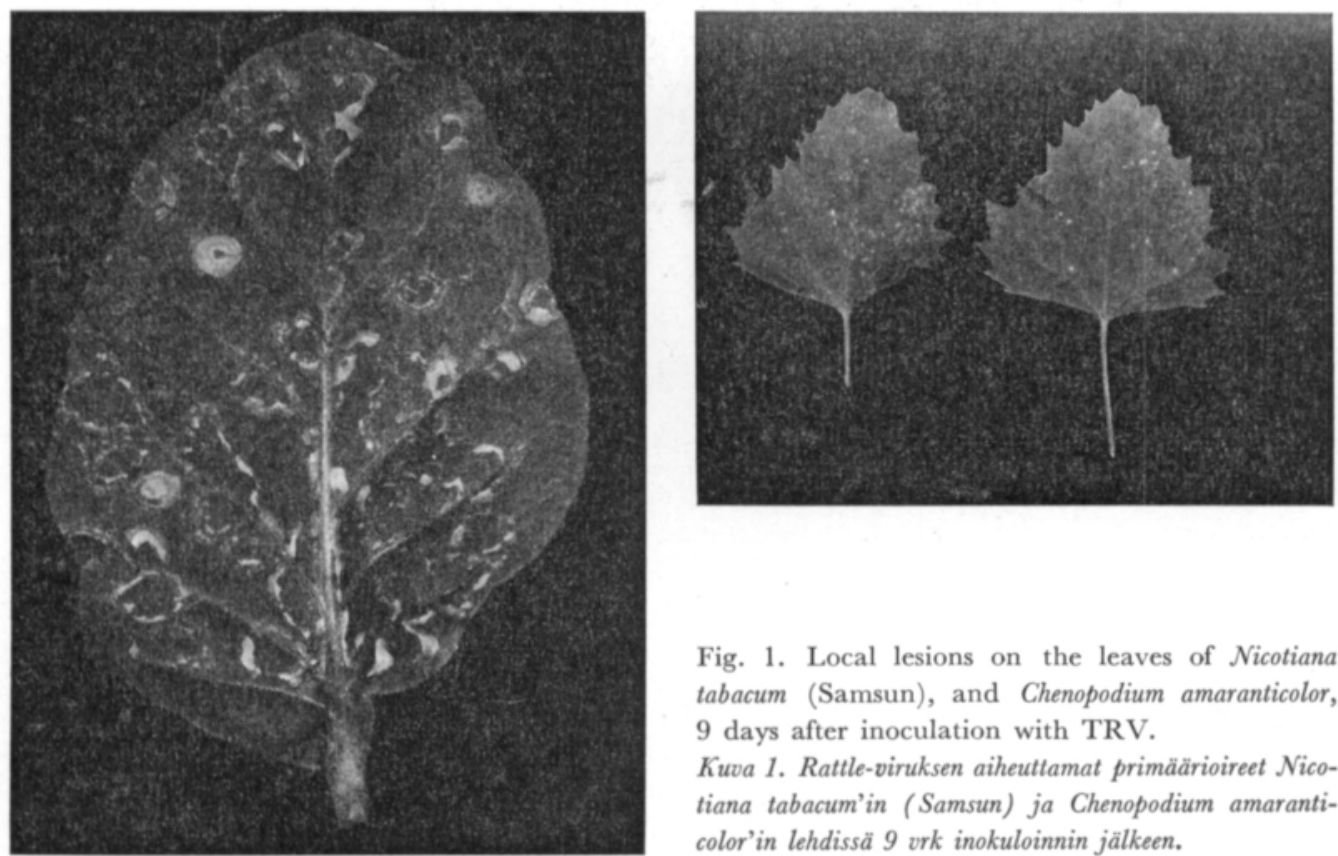

Fig. 1. Local lesions on the leaves of Nicotiana tabacum (Samsun), and Chenopodium amaranticolor, 9 days after inoculation with TRV.

Kuva 1. Rattle-viruksen aiheuttamat primäärioireet Nicotiana tabacum'in (Samsun) ja Chenopodium amaranticolor'in lehdissä 9 vrk inokuloinnin jälkeen.

Resistance to spraing. During 1968-71 ten table potato varieties commonly grown in Finland: Amyla, Bintje, Eigenheimer, Jaakko, Olympia, Pito, Realta, Record, Sieglinde and Valtti were grown in sandy soil at Tikkurila to test the resistance of their tubers to mechanical damage. From 1968 through 1970 all the seed potatoes originated from the South Savo Exp. Station, where seed potatoes for trials are propagated under disease-controlled conditions, and they were free from viruses except for virus $\mathrm{S}$ in some varieties. In 1971 part of the seed potatoes used were saved from the previous crop and were infected with TRV.

The first spraing symptoms were detected in 1968 in the varieties Eigenheimer, Jaakko and Pito. Valid comparisons of varietal susceptibility were not possible until 1970-71. Only secondary symptoms in the haulm of a few plants were detected in 1971. The leaves and partly also the stems were deformed and dwarfed (Fig. 2). Yellowish mottled leaves were present, but the crop suffered from drought and therefore it was not possible to get any detailed records regarding the varietal responses of the haulms to TRV. Strikingly deformed leaves were present in Amyla, Eigenheimer, Jaakko, Olympia, Pito, Sieglinde and Valtti. 


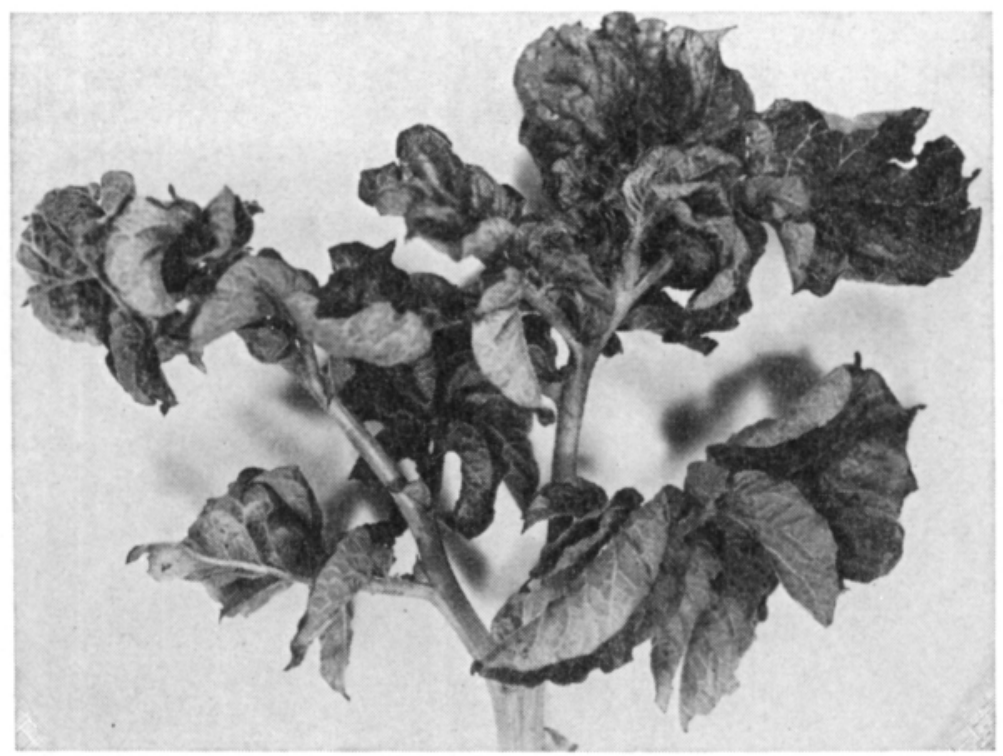

Fig. 2. Severe secondary symptoms in the variety Sieglinde.

Kuva 2. Voimakkaat sekundäärioireet Siiklissä.

Tubers were harvested normally each year starting in 1968 and examined the following spring (in February in 1972). Tubers were halved through their largest diameter and the extent of necrosis was rated as follows:

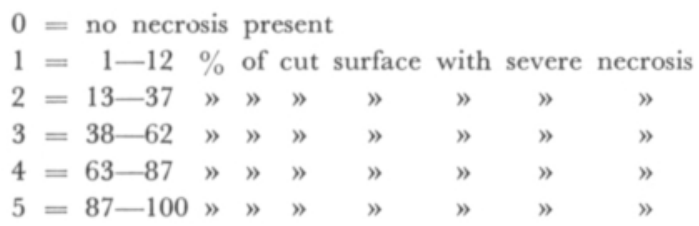

Percentages of tubers affected and mean values of the extent of necrosis were calculated. This assesment method is not as exact as those used by Harrison (1968) and Alonso and Preece (1970) but is proper for comparing varieties. Furthermore, if tuber necrosis is common and the samples large enough, differences in assessment methods have little or no effect on the results.

\section{$T R V$ in Finland}

TRV has probably existed tens of years here without being detected until spraing symptoms were seen in potato tubers grown in a trial field in which potatoes had been grown for a number of years successively. In addition to this, spraing symptoms were recognized in ten samples of tubers sent by growers to the Department of Plant Pathology 


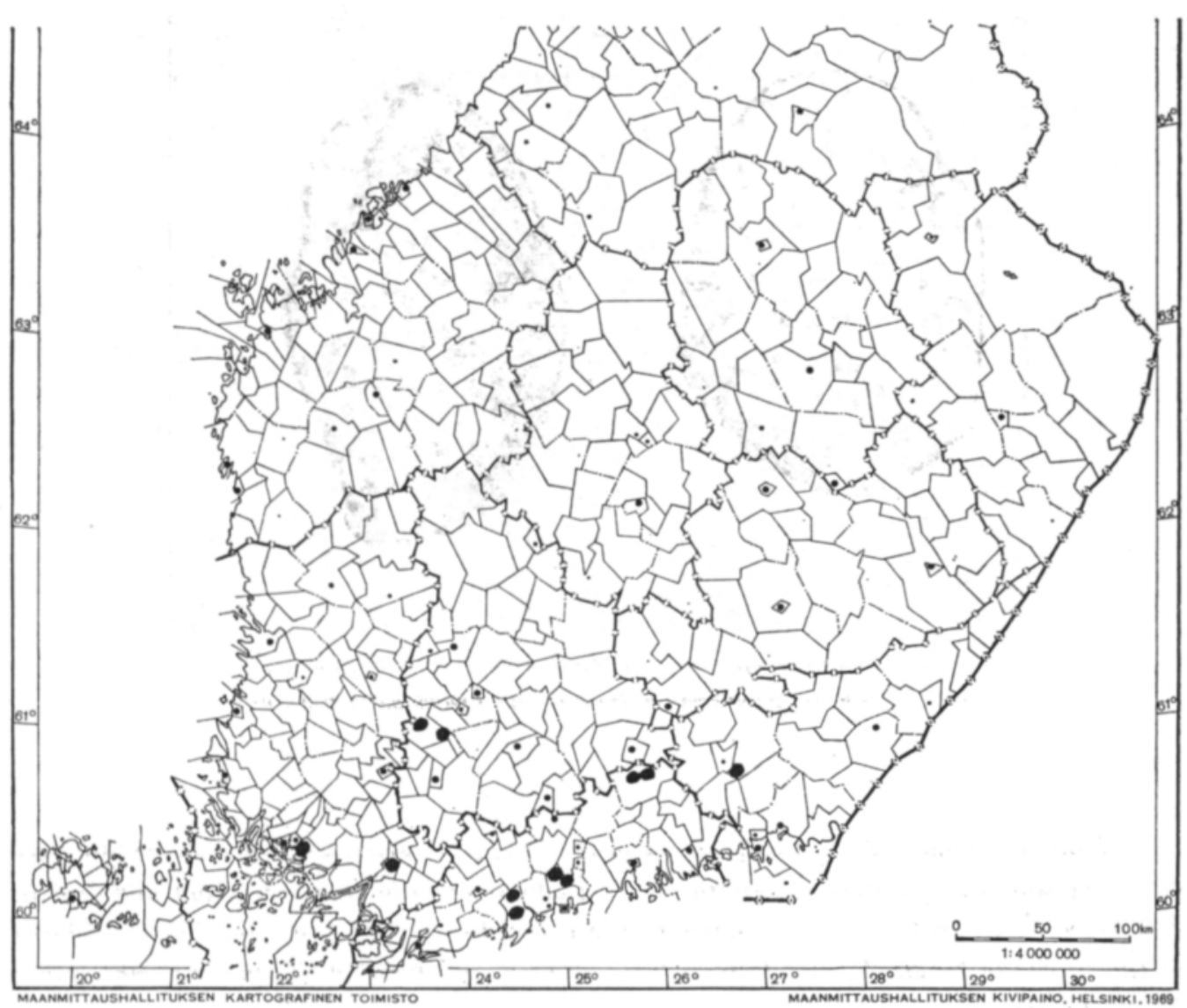

Fig. 3. Dots indicate the origins of tubers with spraing sent to the Department of Plant Pathology. Kuva 3. Paikkakunnat, joilta lähetetyissä näytteissä todettiin viruksen aiheuttamaa mukulanekroosia.

during the years 1968-71 (Fig. 3). Probably the occurrence of TRV (and PMTV) is more widespread than is indicated in the figure but, in any case, TRV is of no importance in commercial potato production in our country. First, most of the tubers sent in were grown in gardens where potatoes had been grown year after year in the same plot. This has not been done in commercial cropping. Second, in the course of studies concerning the quality of table potatoes and ring rot, attention was paid to the occurrence of spraing, but in more than one thousand samples examined no tubers with spraing were detected even though the susceptible varieties Eigenheimer and Pito made up the majority of the lots (Fig. 4).

\section{Resistance of varieties}

Varieties have been examined for the presence of spraing since 1968 but because the field was not uniformly infected the first reliable results were not obtained until 1970 . 


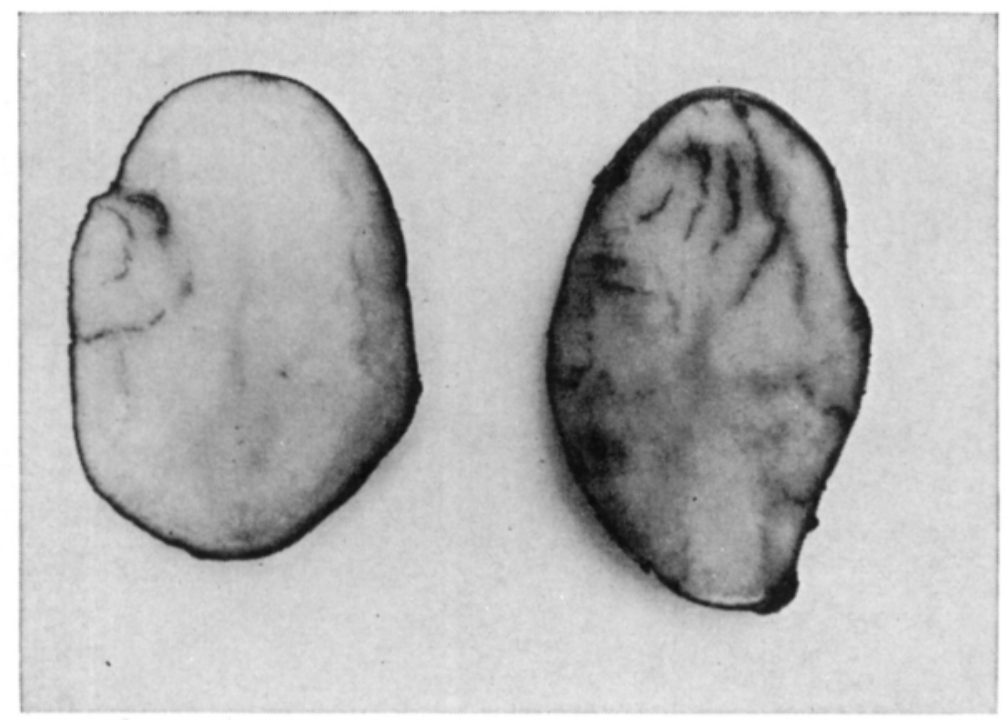

Fig. 4. Spraing symptoms of TRV in tubers of Eigenheimer.

Kuva 4. TRV:n aiheuttamaa mukulanekroosia Eigenheimerin mukuloissa.

The results in Table 1 show the great variation between varieties. Most susceptible were Sieglinde and Pito; rather susceptible were Jaakko, Eigenheimer, Olympia and Valtti. Amyla, Realta and Record were fairly resistant and Bintje very resistant. About a fourth of the tubers of Sieglinde and Pito showed necrosis and most of the necrosis was severe (2-5 rating).

Table 1. The incidence of spraing symptoms in ten varieties. Means of results obtained in 1970 and 1971.

\begin{tabular}{lrrrrrrr} 
Variety & \multicolumn{6}{c}{$\begin{array}{l}\text { Percentage of tubers having different severities of } \\
\text { spraing (See text) }\end{array}$} \\
& 1 & 2 & 3 & 4 & 5 & $\begin{array}{c}\text { Total } \\
\text { Yhteensä }\end{array}$ \\
& & & & & & \\
Index ${ }^{1}$ ) & \\
Sieglinde & 8 & 5 & 4 & 7 & 2 & 26 & 11 \\
Pito & 11 & 11 & 7 & 2 & 1 & 32 & 9 \\
Jaakko & 10 & 4 & 4 & 3 & 1 & 22 & 7 \\
Eigenheimer & 5 & 4 & 3 & 3 & 1 & 16 & 6 \\
Olympia & 4 & 4 & 6 & 2 & 1 & 17 & 6 \\
Valtti & 12 & 6 & 3 & 2 & 0 & 23 & 5 \\
Amyla & 4 & 1 & 1 & 0 & 0 & 6 & 1 \\
Record & 2 & 1 & 0 & 0 & 0 & 3 & 0.4 \\
Realta & 1 & 1 & 0 & 0 & 0 & 2 & 0.3 \\
Bintje & 0 & 0 & 0 & 0 & 0 & 0 & 0
\end{tabular}

1) The index was obtained by using the mid-point values of $\%$ necrosis in each of the rating classes (i.e. 6, 25, 50, 75 and $94 \%$ for the ratings 1, 2, 3, 4 and 5, respectively), multiplying the number of tubers in each rating class by its respective \% necrosis, and dividing by 100 . 


\section{Discussion}

The results obtained concerning varietal resistance to spraing caused by TRV are fairly similar to those reported elsewhere. According to Köstrin (1962) Amyla, Olympia and Sieglinde are susceptible. The susceptibility of Sieglinde has also been reported by Kristensen and ENGSBRo (1966) and that of Eigenheimer by van Hoof (1964). The resistance of Bintje was established by van Hoof (1964), KRISTENSEN and ENGSBro (1966), and Harrison (1968).

It was stated earlier that rattle is very uncommon in Finland. This is fairly surprising because according to Lihnell (1958) spraing is rather common in Sweden (cf. Persson 1968). It is rather common also in Denmark (HANSEN 1962, KRISTENSEN 1962, Kristensen and Engsbro 1966). Although rattle is of no present importance in our country attention has to be paid to its occurrence. Because the number of farmers specializing in potato growing is increasing the probability that all soil borne diseases will increase becomes greater.

\section{REFERENCES}

Alonso, A. B. \& Preece, T. F. 1970. Assesment of spraing caused by tobacco rattle virus in potato tubers. Pl. Path. 19: 25-28.

BJørnstad, A. 1962. Stengelbont på potet. Bondevennen 1962: 594-596, 622-624.

BJønstad, A. 1969. Spredning av Potet-mopp-topp-virus (PMTV) med settepoteter. Jord og Avl. 1969, 2: $1-4$.

Brandenburg, E. \& Eibner, R. \& Tostman, R. 1959. Untersuchungen über die Eisenfleckigkeit-Propfenbildung der Kartoffel als bodengebundene Viruskrankeit. Mitt. biol. Bundesanst. 97: 36-51.

Cadman, C. H. \& Harrison, B.-D. 1959. Studies on the properties of soil-borne viruses of the tobaccorattle type occurring in Scotland. Ann. appl. Biol. 47: 542-556.

Calvert, E. L. 1970. Mop Top Virus. Agr. North. Ire. 45: 82-85.

Calvert, E. L. \& Harrison, B. D. 1966. Potato mop-top, a soil-borne virus. Pl. Path. 15: $134-139$.

EIBNER, R. 1961. Untersuchungen über das vorkommen von Tabak-mauche-bzw. Ratelvirus in Westdeutschland. Nachrbl. Deut. Pfl.schutzd. (Braunschweig) 13: 104-105.

Hansen, S. E. 1962. Rattlevirus i kartofler. Statens Plantepatologiske Forsøg, Månedoversigt 394: 20 -24.

Harrison, B. D. 1968. Reactions of some old and new British potato cultivars to tobacco rattle virus. Eur. Potato J. 11: 165-176.

Hoof, H. A. van 1964. Het tijdstip van infectie en veranderingen in de concentratie van Ratelvirus (Kringerigheit) in de aardappelknol. Meded. Landb. hogesch. Opzoekingssta. Staat Gent 29: $944-955$.

Kristensen, H. R. 1962. Jordbårne plantevira. Tidsskr. for Planteavl 66: 75-148.

Kristensen, H. R.\& Engsbro, B. 1966. Undersøgelser og forsøg vedrøende jordbårne vira. I. Rattle-virus. Tidsskr. for Planteavl 70: 353-379.

Köstlın, H. 1962. Weitere Untersuchungen über das bodengebundene Ratelvirus an Kartoffeln. Diss. Giessen. (Ref. Steck, U. 1971.)

Lihnell, D. 1958. Investigations on spraing. Proc. 3rd Conf. Potato Virus Dis. 1957, Lisse-Wageningen: $184-188$.

Persson, S. 1968. Nematoder av släktet Trichodorus i syd-svenska åkerjordar och deras förmåga att överföra rattelvirus. Nat. Swe. Inst. Plant Prot. Contr. 14: 163-199.

RoozendaAl, A. 1947. Ziekten van het stengelbont-type bij de aardappel. Tijdschr. Pl.ziekt. 53: 93101. 
Roozendal, A.\& van Der WANT, J. P. H. 1948. Over de identiteit van het ratelvirus van de tabak en het stengelbontvirus van de aardappel. Tijdschr. Pl.ziekt. 54: 113-133.

Sol, H. H. \& Heuven, J. C. van \& Seinhorst, J. W. 1960. Transmission of rattle virus and Atropa belladonna mosaic virus by nematodes. Ibid. 66: 228 .

STECK, U. 1971. Zur Biologie, Ökologie und Bekämpfung des Tabak-Rattle-Virus (TRV) im Kartoffelbau. (Eine Literaturstudie) Bayerisches landw. Jahrb. 48: 867-891.

Todp, J. M. 1965. Soil-borne virus diseases of potato. Scott. Pl. Breed. Sta. Rec. 1965: 209-235.

Todn, J. M. 1967. Soil-borne virus diseases of potato. N.A.A.S. Quat Rev. 77: 21-29.

Walkishaw, C. H. \& Larson, R .H. 1959. Corky ringspot of potato. Univ. Wis. Res. Bull. 217: 1-31.

\title{
SELOSTUS
}

\section{TUPAKAN RATTLE-VIRUS SUOMESSA JA 10 PERUNALAJIKKEEN KESTÄVYYS SEN AIHEUTTAMAA MUKULANEKROOSIA VASTAAN}

\author{
EsKo SEPPÄNEN
}

Kasvitautien tutkimuslaitos, Maatalouden tutkimuskeskus

Vuonna 1968 todettiin Tikkurilassa erään koelohkon perunoissa mukulanekroosia (kuva 4), joka osoitettiin tupakan rattle-viruksen (TRV) aiheuttamaksi (kuva 1). Vastaavanlaisia mukuloita on Kasvitautien tutkimuslaitokselle lähetetty useilta paikkakunnilta Etelä-Suomesta (kuva 3). Taudin merkitys on meillä ainakin perunassa vähäinen, sillä äskettäin suoritettujen ruokaperunan laatua ja rengasmädän levinneisyyttä koskevien tutkimusten yhteydessä kiinnitettiin huomiota myös tämän taudin esiintymiseen, mutta ainoassakaan mukulassa ei todettu taudin oireita. Taudin levittäjiä ovat meillä harvinaisen ankeroissuvun Trichodorus lajit. Perunanviljelyn erikoistumisen yleistyessä on kiinnitettävä huomiota myös tähän tautiin.

Tikkurilassa taudin saastuttamassa maassa kasvaneiden 10 meillä yleisesti viljellyn lajikkeen mukuloiden kestävyydestä tehdyt havainnot on esitetty taulukossa 1. Eigenheimer, Pito ja Siikli (Sieglinde) olivat altteimmat, melko alttiita olivat Amyla, Jaakko, Olympia ja Valtti. Realta ja Rekord olivat melko kestäviä ja Bintje kestävä. Ulkomaisissa tutkimuksissa esitetyt tiedot Eigenheimerin, Siiklin, Amylan, Olympian ja Bintjen kestävyydestä ovat yhtäpitäviä nyt saatujen tulosten kanssa. Muiden lajikkeiden kestävyydestä ei aikaisempia tuloksia ole käytettävissä. 